\title{
TRADITIONAL VS MODERN APPROACHES TO MEASURING THE PERFORMANCE OF A COMPANY
}

\author{
Zoran Jovići ${ }^{1 *}$ \\ Stevan Tomašević ${ }^{2}$ \\ ${ }^{1}$ Singidunum University, \\ Belgrade, Serbia \\ ${ }^{2} \mathrm{PhD}$ candidate, \\ Singidunum University, \\ Belgrade, Serbia \\ Novi Sad School of \\ Business, \\ Novi Sad, Serbia
}

\begin{abstract}
:
The process of managing the performance of a company necessarily goes through the phase of their measurement. The measures that are applied depend on the information requirements, the set goals, and the defined business strategy of the company. The traditional approach to measuring company performance places emphasis on financial parameters that are expressed quantitatively, thus creating the possibility of dynamic observation of the phenomenon in continuous time periods. In contrast to this approach, the modern approach, in addition to financial, uses non-financial performance measures that are expressed and categorized qualitatively, in accordance with the needs of key stakeholders. The focus of the traditional approach is on analyzing and improving the short-term performance of the company, while the modern approach is dominated by the pursuit of long-term company value.
\end{abstract}

Keywords:

business performance, traditional approach, modern approach.
Correspondence:

Zoran Jović

\section{INTRODUCTION}

The paper will explain the basic characteristics of the two title approaches to measuring performance, as well as the most used traditional and modern measures (models) of company performance.

Traditional business performance indicators use an accounting information system as a source of data to monitor, measure and report on a company's financial performance. These indicators are the basis for making adequate business decisions and for managing the company's operations, and they are also a good tool for external financial reporting.

On the other hand, the modern approach to measuring the performance of companies seeks to overcome the one-dimensionality of the traditional approach to measuring performance. Although the financial dimension treated by the traditional approach is basic and very important, it is not the only one. For a modern company to survive in a competitive business environment, it must take into account, in addition to financial, non-financial aspects of business success. The characteristic of the modern business environment is the accelerated growth and development of companies, accelerated development and application of technological achievements, globalization and the like. For a company to achieve a comparative advantage over its competitors, it must continuously invest in knowledge, new technologies and the development of its employees. Creating a competitive advantage contributes to creating added value and raising the company's business performance to the highest possible level. 
However, for a company to operate efficiently in such extremely competitive conditions, it must create and use an adequate system for measuring the company's performance. Such a system should enable it to continuously analyze and improve performance measures in order to harmonize and adjust to the new situation in the company. (Janjić, Todorović, \& amp; Jovanović, 2015).

\section{TRADITIONAL PERFORMANCE MEASURES}

Traditional indicators are mainly based on the concept of accounting profit, and this is their basic characteristic. In doing so, the profit is viewed as the net operating result, i.e., the difference between income and related expenses of the same accounting period. This means that traditional indicators are focused on the data and information presented in the financial statements of corporations, i.e., in the balance sheet, income statement, cash flow statement, statement of changes in equity, statement of other results, etc. Hence, these indicators are historical in nature, i.e., ex-post indicators, as they include data from the previous period and observe events that occurred in the past. This method, based on such information, analyzes everything that happened in the previous reporting period, because of which corrective measures are taken and business plans for the future period are defined.

The concept of accounting profit, on which traditional indicators are based, has its advantages: because profit as a final result is based on business transactions that were realized during the year and on the principle of historical value; because it provides adequate business decisionmaking and control; because, unlike economic profit, accounting profit is easily determined; because it has a wide application in the financial reporting of the largest number of economic entities in our area (Malinić, 1999).

Also, as advantages of traditional indicators based on data from financial statements, it is stated that they meet a number of performance measurement criteria such as accuracy, objectivity, comprehensibility, controllability, data availability, ability to measure in short periods of time, the ability to rely on international accounting and financial reporting standards and auditability. (Merchant, \& amp; Van der Stede, 2007).

The shortcomings of traditional indicators are (Domanović, 2010) that they can lead to wrong conclusions and bad business decisions because they are based on past events, on what has already happened in the previous period, and not on what has happened, is currently happening or will happen in the coming period. In addition, a significant disadvantage lies in the fact that the data provided in the financial statements can be easily manipulated and thus provide a false picture of the success of a company. Also, these indicators may have different values in firms operating in different geographical areas due to differences in the application of legal, professional, and internal regulations.

The shortcomings of the traditional, ex-post concept based on accounting profit have led to the development of an ex-ante concept based on economic profit. This concept is determined on the basis of expectations and it contains elements of the projected future and takes into account the opportunity cost which is not shown in the income statement. According to this concept, profit forms the basis for rational behavior and making adequate business decisions. Based on the projected future, the benefits of available capital are predicted by discounting cash flows realized in different time periods and reducing them to present equivalents. (Pešalj, 2016).

Accounting and economic profit are similar, but differ in that accounting profit includes only interest costs incurred on the basis of loans, while economic profit includes the cost of total capital. According to the concept of accounting profit, equity, unlike borrowed capital, does not require cash outflows, which means that the cost of equity is not paid and has the character of opportunity costs. Thus, capital owners can invest their capital in other business activities and thus make an additional return. Therefore, the concept of economic profit or economic added value requires that equity, as well as borrowed capital, must include certain costs, and that they must be calculated and reimbursed like all other costs. (Krstić, \& amp; Bonić, 2017)

In addition to the advantages and opportunities provided by traditional financial indicators, there are numerous disadvantages of these indicators that call into question the justification of their application (Krstić, \& Sekulić, 2007). The disadvantages lie in the fact that the accounting information system is based on data from the past, which can lead to obsolescence of information at the time of reporting. Also, due to the short-term dimension of financial indicators, there may be an inadequate and incomplete assessment of business success, which may be the cause of undertaking activities that are not in line with the strategic goals of the company. In addition, the effort of management to achieve the highest possible profit in a certain period under the pressure of measuring the results of their personal engagement can lead to neglect or delay of necessary investments in research and development, which neglects the long-term goals of the company. Furthermore, traditional indicators are not of the same importance for all parts of the corporation, because employees at lower levels usually do not have a clear idea of the connection between their work and the value of these indicators. The disadvantage is that traditional indicators neglect the importance of other dimensions such as product quality, customer and employee satisfaction, delivery time, which can all lead to misinformation about the efficiency and profitability of the company's business. 
However, despite these shortcomings, most financial and business analyses that rely on financial and management accounting are based on traditional financial indicators.

\section{MODERN PERFORMANCE MEASURES}

It is difficult to cover all the necessary aspects of a company's business success through a performance measurement system, but the task of the company's top management is to choose an adequate performance measurement system for their company. In making that choice, management should take into account both the financial and non-financial dimensions of the business. Non-financial performance measures do not arise from the annual financial statements, as is the case with financial measures, so they have less pressure on the time dimension of the deadline for meeting the defined performance of the company. Also, non-financial performance measures have a much better effect on the clarity of the role played by employees, managers and organizational parts of the company. According to Milosavljević and Mayer (Milosavljević, 2015; Meyer, 2002), they are ubiquitous and are a function of the firm, i.e. they represent what the firm is engaged in. Non-financial measures can be expressed in different ways because they are not in monetary form.

As critical success factors, the modern approach to performance measurement places emphasis on measuring a smaller number of variables, on the connection of performance measures with success factors and defined company strategy, on providing insight into information through all three time dimensions, i.e. information on past, present and future events, to observe all organizational parts of the company and all levels of business activity, not just the company as a whole, to observe all relevant resources of the company (Domanović, 2010).

Modern performance measurement systems include the following measures (Fitzgerlad, 2007):

- Criteria of results that indicate the success of the company after the completion of a certain process (market share, revenue, profit, etc.);

- Input and process criteria that indicate the success of the company before the end of the process, thus creating the possibility to make the necessary corrections (time, work invested, process duration, capacity utilization, etc.).

There are many advantages of modern performance measures, and the main advantages are that they eliminate the disadvantages of traditional measures. Unlike traditional measures, modern measures include both financial and non-financial measures, they are determined from both accounting and non-accounting sources, they are determined by lower organizational parts of the company and not only by the company as a whole, they are determined by product life cycle stages and alternative strategies (Dajić, \& Todić, 2017), and therefore improve the allocation of resources, improve the decision-making process and the like.

There are three different directions in the development of modern financial performance (Tadić, 2015):

- Adjusted financial indicators that eliminate shortcomings and that are adjusted to the needs of a modern company (rate of return on invested capital);

- Cash flow indicators (cash return on invested capital, discounted cash flow);

- Indicators based on the concept of economic profit (market value added and economic value added).

The above-mentioned modern performance measures are based exclusively on financial information, but in order to create a complete picture of the results achieved by a company, it is necessary to use non-financial measures. According to Burch (Burch, 1994) the company should use the following measures:

- Performance measurement in relation to suppliers (quality of delivered product, delivery time);

- Performance measurement based on time (processing time, production movement time, waiting time);

- Measuring productivity performance (labor productivity, direct material yield, activity productivity);

- Measuring performance in relation to meeting the needs of consumers (sales activity, number of orders, delivery time).

\subsection{THE CONCEPT OF ECONOMIC VALUE ADDED}

Modern business conditions have led to the need to create and adopt a new management concept aimed at value creation (VBM - Value Based Management). Other concepts of value creation have developed from the mentioned VBM concept, and one of the most significant is EVA - Economic Value Added. This concept of added economic value is based on the concept of economic profit as the difference between net profit and cost of equity. EVA measures the company's economic profit instead of accounting profit, i.e. it measures the level at which the company's profit exceeds the rate of return on invested capital. Thus, EVA measures the company's realized profit after deducting all capital costs. Hence, it can be concluded that the company will create added value as long as the rate of return on invested capital is above the average price of invested capital, i.e. as long as EVA is positive, and vice versa, if EVA is negative, the company's value will fall because revenues are not enough to cover total capital costs. 
Particular attention within the EVA concept should be paid to the factors that affect the increase in value created, namely (Stewart, 1991; Zakić, 2011; Alihodžić, 2013):

- increase in the rate of return on invested capital,

- profitable growth is achieved by those investments that bring a higher expected rate of return than the costs of the investment itself,

- sale or abandonment of those investments or organizational parts of the company that are not profitable, which leads to a decrease in invested capital and to an increase in the difference between the rate of return and the cost of equity,

- reduction of capital costs, i.e. selection of the capital structure that will lead to minimization of total capital costs,

- extension of the period of expected positive cash flows of investments.

In Serbia, the EVA concept as a modern method of measuring company performance is being applied to an increasing extent. One study conducted on this topic (Todorović, Kaličanin, \& Nojković, 2015) came to the following results:

- about $83 \%$ of managers rely on absolute measures of accounting profit when assessing the performance of the company;

- in 2/3 of companies, relative measures of accounting metrics are applied, such as: rate of return on assets, rate of return on capital, rate of return on invested capital, etc .;

- modern performance measures are used much less compared to traditional measures, and in terms of the application of modern measures, the presence of Economic Value Added (EVA) and the Balanced Scorecard dominate;

- although modern measures are very poorly applied, there is significant progress in their application compared to previous research.

- EVA is constantly used in $1 / 4$ of the total number of surveyed companies;

- EVA is statistically significantly more used in large companies compared to small companies, as well as in companies with the international business compared to companies that operate exclusively in the domestic market.

\subsection{BALANCED SCORECARD IN THE FUNCTION OF MEASURING THE PERFORMANCE OF THE COMPANY}

The performance management concept, called the Balanced Scorecard by Robert Kaplan and David Norton, is now present in companies around the world. Due to the possibility of the practical application of the performance measurement system, this model has quickly gone from a model designed to measure the effects of applied strategies of organizational units and enterprises as a whole, to an instrument of execution and application of enterprise strategy.

The concept of the Balanced Scorecard has managed to solve the big problems faced by the managers of many, especially large companies, in connection with the imperfection of various criteria and the previous way of measuring the performance of companies. It is on the weaknesses of earlier systems that this concept has developed its advantage. The essence of the Balanced Scorecard is reflected in the definition of a grouped overview of measures that will give managers a clear and comprehensive overview of the company's operations. Traditional performance measures, such as return on capital and earnings per share, can give a completely wrong picture of the real situation in the company in the conditions of constantly present innovations and changes in the company's business. Traditional measures have been useful as measures of enterprise performance only in the period of industrialization, but their application, and especially independent application, has no purpose in companies operating in an era of increased competition and technological progress. That is why the concept of the Balanced Scorecard, in addition to financial measures, also uses non-financial measures. Non-financial measures are all those measures that indicate customer satisfaction, internal processes and activities to improve the organization. In this way, company managers have the opportunity to evaluate the success of the company from the following four perspectives (Janićijević, 2009):

- Consumer perspective that includes the performance of the company in the market and in terms of consumer satisfaction (quality of product or service, price, service, warranty, delivery time, etc.);

- Perspective of internal processes, which includes the performance of the company in terms of efficiency of internal business processes (length of the production process, percentage of scrap, the efficiency of material use, etc.);

- Perspective of innovation and learning, which includes the performance of the company in innovating and acquiring new knowledge (time of new product development, participation of the new product in total sales, number of proposed innovations by employees, etc.); 
- Financial perspective that includes typical financial performance measures (return on invested capital, liquidity ratio, indebtedness ratio).

This division provides the management of the company with the necessary information from different perspectives, without the application of this concept in particular, the company does not have to include all four of these perspectives. How much and what perspectives a company will use depends on factors such as the size of the company, the activity of the company, the location where it is located, and the like. In some companies, preference will be given to only one in relation to other perspectives, and in another company, observing only one perspective will be enough to make appropriate conclusions about business success.

It is important that the list of performance measures is not too wide so that the company's management can focus and monitor the movement of selected performance.
On the other hand, the number of measures should not be too small, because the use of only two or three measures within one perspective cannot adequately describe the strategy, as well as the relationship between performance and their bearers.

There is no single set of selected performance measures. Each set will show its usefulness only in the context of individual goals and strategies. Most companies that use this concept, regardless of their size, apply a small number of measures, usually from 20 to 30 . The essence is that managers should focus on key strategic drivers of performance, or several variables that mostly affect the success of their company.

The following table will show some of the measures that managers could use in the process of measuring performance through the Balanced Scorecard, which is categorized according to the stated perspectives.

Table 1. Basic performance measures presented according to the perspectives of the Balanced Scorecard

\begin{tabular}{llll}
\hline \multicolumn{1}{c}{$\begin{array}{c}\text { Financial } \\
\text { perspective }\end{array}$} & \multicolumn{1}{c}{$\begin{array}{c}\text { Customer } \\
\text { perspective }\end{array}$} & \multicolumn{1}{c}{$\begin{array}{c}\text { Perspective of internal } \\
\text { processes }\end{array}$} & $\begin{array}{c}\text { Perspective of innovation } \\
\text { and learning }\end{array}$ \\
\hline - earnings per share & - probability of recommendation & - average transaction costs & - average work experience \\
- total assets per employee & - loyalty and customer & - delivery on time & - turnover ratio \\
- \% profit from total active & satisfaction & - inventory turnover & - absenteeism \\
- ROA & - market participation & - average duration of the patent & - satisfaction of employees \\
- income per employee & - customer complaints & - lack of stock & - added value per employee \\
- ROE & - resolved appeals in the first & - labor utilization rate & - motivation index \\
- EVA & procedure & - defect percentage & - number of applications for \\
- MVA & - retained or lost customers & - market segmentation & employment \\
- ROI & - annual sales per customer & - guarantee confirmation & - employment index \\
- added value per employee & - spent time with customers & - waste reduction & - quality of the working \\
- market value & - sales by channels & - planning accuracy & environment \\
- share price & - frequency & - reputation index & - health promotion \\
- debt / capital & & &
\end{tabular}

Source: Niven, 2002

The application of the Balanced Scorecard concept is a complicated process that requires a lot of time and effort to adapt the management systems to its application. Many companies have a problem when implementing this system because they do not have a strategic plan, or do not have an official document confirming the existence of a particular strategy.

Even if they have a strategic plan, there is often a problem of not understanding the concept of strategy, especially from employees at lower organizational levels.

\section{COMPARATIVE PRESENTATION OF MODERN AND TRADITIONAL APPROACHES}

The basic characteristics of modern approaches to measuring the performance of companies can best be explained by their comparison with the traditional approach to measuring performance (Table 2). 
Table 2. Comparative overview of traditional and modern approaches to performance measurement companies

\begin{tabular}{llll}
\hline \multicolumn{1}{c}{ Changes to } & \multicolumn{1}{c}{$\begin{array}{c}\text { Traditional } \\
\text { Measurement }\end{array}$} & \multicolumn{1}{c}{$\begin{array}{c}\text { Balanced } \\
\text { Measurement }\end{array}$} & \multicolumn{1}{c}{ Performance Management } \\
\hline FOCUS & Internal & Internal and external & Needs of relevant internal groups \\
\hline DIMENSIONS & Single & Multiple & $\begin{array}{l}\text { Less focus on dimensions and more on the } \\
\text { relationships between dimensions }\end{array}$ \\
\hline DRIVERS & Cost & $\begin{array}{l}\text { Innovation and } \\
\text { learning }\end{array}$ & $\begin{array}{l}\text { Improving process capability through resource } \\
\text { development }\end{array}$ \\
\hline TARGETS & Financial & $\begin{array}{l}\text { Financial and } \\
\text { non-financial }\end{array}$ & Comparative-external and anti-competition \\
\hline DESIRED & Cost control & $\begin{array}{l}\text { Strategic direction } \\
\text { communication }\end{array}$ & $\begin{array}{l}\text { Improving sustainable performance through } \\
\text { improving business processes }\end{array}$ \\
\hline
\end{tabular}

Source: Bourne, Franco, \& Vilkes, 2003

Calculated indicators should be compared with standard values such as: expected (planned) indicators, indicators of the same company from the previous period, indicators calculated in other companies of the same activity, etc.

\section{CONCLUSION}

Unlike developed countries, where the application of this concept is considered a regular practice in the process of measuring the performance of companies in the Republic of Serbia, this system is still not so developed, and it is used by about $1 / 5$ of companies, mainly large companies, international companies and companies whose shares are listed on the stock exchange. The application is dominated by the concept of economic value added (EVA) and the concept of Balanced Scorecard. The reasons for less usage of modern performance measures (Todorović, Kaličanin, \& Nojković, 2015) in the Republic of Serbia lie in the insufficient information of managers about these measures, in the complexity of use, time and costs required to implement these measures.

Major changes in business resulting from the global COVID-19 pandemic impose the need to apply modern measures of company performance in the process of managing a business in a constantly changing business, social and cultural environment. Improving and expanding modern enterprise performance measures fits into the current ContinuousNext ${ }^{\circ}$ approach so that every company can adapt to rapid changes in technology, competition, and business.

In future research, it would be desirable to compare data on the application of modern enterprise performance in the years before and after the global pandemic, and general changes in the environment.

\section{LITERATURE}

Alihodžić, A. (2013). Possibility of Applying Economic Value Added in the Capital Market of the Republic of Srpska. Singidunum Journal, 10(2), 7-18.

Bourne, M., Franco, M., \&amp; Wilkes, J. (2003). Corporate performance management. Measuring Business Excellence, 7(3), 15-21.

Burch, J. G. (1994). Cost and Management Accounting: a Modern Approach. West Publishing Company.

Dajić, M., \&amp; Todić, M. (2017). Merenje i unapređenje indikatora ključnih performansi u savremenim kompanijama. Anali poslovne ekonomije, 16, 52-59.

Domanović, V. (2010). Balanced Scorecard - mogućnosti i efekti primene. Kragujevac: Ekonomski fakultet.

Fitzgerald, L. (2007). Performance Measurement. U: Management Accounting (3rd edition), ured: Hopper, T., Northcott, D., \&amp; Scapens, R., 223-244.

Janićijević, N. (2009). Implikacije koncepta Balanced Scorecard na organizaciono ponašanje. XIV Internacionalni naučni skup: Palić: Ekonomski fakultet Subotica.

Janjić, V., Todorović, M., \& amp; Jovanović, D. (2015). Komparativna analiza savremenih modela merenja upravljanja performansama preduzeća. Ekonomske teme, 53(2).

Krstić, B., \&amp; Bonić, Lj. (2017). Poslovna analiza i kontrola - instrumenti unapređenja konkurentnosti preduzeća. Niš: Ekonomski fakultet.

Krstić, B., \&amp; Sekulić, V. (2007). Upravljanje performansama preduzeća. Niš: Ekonomski fakultet.

Malinić, D. (1999). Politika dobiti korporativnog preduzeća. Beograd: Ekonomski fakultet.

Merchant, K.A, \&amp; Van der Stede, W.A. (2007). Management Control Systems - Performance Measurement Evaluation and Incentives. Harlow: Pearson Education.

Meyer M.W. (2002). Rethinking performance measurement: beyond the Balanced Scorecard. Cambridge. UK: Cambridge University Press. 
Milosavljević, M. (2015). Integralni sistem upravljačkog računovodstva za merenje poslovnih performansi (doktorska disertacija). Beograd: Fakultet organizacionih nauka.

Niven, P.R. (2002). Balanced Scorecard step-by-step: Maximizing performance and maintaining results. NY: John Wiley \&amp; Sons.

Pešalj,B.(2016).Merenjeperformansipreduzeća:tradicionalni i savremeni sistemi i primena. Beograd: Centar za izdavačku delatnost Ekonomskog fakulteta.

Stewart, B. (1991). The Quest for Value: The EVA Management Guide. New York: Harper Business.

Tadić, J. (2015). Modeliranje upravljanja performansama organizacije preduzeća u funkciji optimiranja ekonomskog uspeha (doktorska disertacija). Novi Sad: Ekonomski fakultet Subotica.

Todorović, M., Kaličanin, Đ., \&amp; Nojković, A. (2015). Prakse merenja performansi u preduzećima u Republici Srbiji. Ekonomski horizonti, 17(1), 45-59.

Zakić, V. (2011). Dodata ekonomska vrednost kao merilo generisanja vrednosti za akcionare. Škola biznisa, 1, 53-61. 